\title{
Hypoxia-dependent signaling in perioperative and critical care medicine
}

\author{
Kiichi Hirota ${ }^{1}$
}

Received: 20 May 2020 / Accepted: 24 April 2021 / Published online: 18 May 2021

(c) Japanese Society of Anesthesiologists 2021

\begin{abstract}
A critical goal of patient management for anesthesiologists and intensivists is to maintain oxygen homeostasis in patients admitted to operation theaters and intensive care units. For this purpose, it is imperative to understand the strategies of the body against oxygen imbalance-especially oxygen deficiency (hypoxia). Adaptation to hypoxia and maintenance of oxygen homeostasis involve a wide range of responses that occur at different organizational levels in the body. These responses are greatly influenced by perioperative patient management including factors such as perioperative drugs. Herein, the influence of perioperative patient management on the body's response to oxygen imbalance was reviewed with a special emphasis on hypoxia-inducible factors (HIFs), transcription factors whose activity are regulated by the perturbation of oxygen metabolism. The 2019 Nobel Prize in Physiology or Medicine was awarded to three researchers who made outstanding achievements in this field. While previous studies have reported the effect of perioperatively used drugs on hypoxia-induced gene expression mediated by HIFs, this review focused on effects of subacute or chronic hypoxia changes in gene expression that are mediated by the transcriptional regulator HIFs. The clinical implications and perspectives of these findings also will be discussed. Understanding the basic biology of the transcription factor HIF can be informative for us since anesthesiologists manage patients during the perioperative period facing the imbalances the oxygen metabolism in organ and tissue. The clinical implications of hypoxia-dependent signaling in critical illness, including Coronavirus disease (COVID-19), in which disturbances in oxygen metabolism play a major role in its pathogenesis will also be discussed.
\end{abstract}

Keywords Anesthesia $\cdot$ Hypoxia $\cdot$ Hypoxia-inducible factor $\cdot$ Oxygen metabolism $\cdot$ Perioperative care

\section{Introduction}

One of the most critical goals of patient management in operation theaters and intensive care units, for anesthesiologists and intensivists, is to maintain appropriate oxygen homeostasis in patients [1-3]. For this purpose, it is essential to understand the strategies of the body against oxygen imbalance, especially oxygen deficiency (hypoxia) [4, 5]. Adaptation to hypoxia and maintenance of oxygen homeostasis involves a wide range of responses that occur at different organizational levels in the body [6,7].

Oxygen plays an essential role in efficient ATP production in mitochondria. Glucose is transformed to pyruvate via

Kiichi Hirota

khirota-kyt@umin.ac.jp

1 Department of Human Stress Response Science, Institute of Biomedical Science, Kansai Medical University, Hirakata, Japan glycolysis. Pyruvate is then converted to acetyl coenzyme A (acetyl-CoA) flowing into the tricarboxylic acid (TCA) cycle in mitochondria to generate ATP via oxidative phosphorylation (OXPHOS). Oxygen acts as the final acceptor for electrons in the electron transport chain (ETC). Thus, mitochondrial OXPHOS is considered essential for cell survival, especially in the brain and heart, which are highly vulnerable to the lack of oxygen [8]. Oxygen is also a critical player in intracellular signal transduction. Reactive oxygen species (ROS) generated from oxygen act as crucial second messengers of intracellular signaling, although they may be toxic to the organism under specific conditions. Elimination of ROS as a messenger can, therefore, disrupt cellular signaling. Oxygen is also used as a substrate for production of prostaglandins, thromboxanes, and leukotrienes from arachidonic acid by oxygenases, in responses mediated by cytochrome 450, and in reactions in which NADPH oxidase produces ROS. 
While a review article focusing on the association between anesthesia and the master factor transcription factor HIF-1 - which controls the hypoxic response-was published nearly 20 years ago [9], research in this field of study has progressed remarkably; the 2019 Nobel Prize in Physiology or Medicine was awarded to three researchers who made outstanding achievements in this field $[8,10]$. Thus, this review is an opportunity to introduce new findings in oxygen biology and describe its application in perioperative medicine. The clinical implications of hypoxia-dependent signaling in critical illness including Coronavirus disease (COVID-19), in which disturbances in oxygen metabolism play a major role in its pathogenesis will also be discussed.

\section{Perioperative patient management and oxygen metabolism}

As human beings do not possess the intrinsic machinery to produce molecular oxygen, oxygen must always be taken into the body through the lungs. When the supply is interrupted, about $1,400 \mathrm{~mL}$ of oxygen retained in an adult body is consumed in approximately $5 \mathrm{~min}$, assuming that oxygen consumption during anesthesia is $250 \mathrm{~mL} / \mathrm{min}[2,11]$. Hence, perioperative management by anesthesiologists in operating theaters depends on a highly precarious balance.

To confirm that the oxygen partial pressure of arterial blood is appropriately maintained during patient care, the color of blood is observed and $\mathrm{SaO}_{2}$ and $\mathrm{PaO}_{2}$ is measured [1]. If the hemoglobin concentration is given, then the oxygen content in arterial blood can be determined with $\mathrm{SaO}_{2}$ and $\mathrm{PaO}_{2}$. The cardiac output confers the oxygen supplying capacity $\left(\mathrm{DO}_{2}\right)$. With the introduction of $\mathrm{SvO}_{2}$ or $\mathrm{ScvO}_{2}$, the $\mathrm{VO}_{2}$ of the patient can be estimated via the Fick method [2] (Fig. 1).

Although it is not possible to determine precisely the balance of oxygen demand and supply in individual organs and tissues by non-invasive monitoring [12], devices using nearinfrared spectroscopy (NIRS) for the measurement have enabled to see the outline of tissue oxygen saturation in a part of the brain noninvasively, almost in real-time [13]. However, these methods do not reveal the state of oxygen metabolism in the cells of individual organs and tissues. Thus, we cannot precisely measure or know the rate of oxygen metabolism or consumption in all the individual cells in the body during anesthetic care [13].

\section{Lack of oxygen and dysregulation of oxygen metabolism}

There are no definitive quantitative criteria for determining the partial pressure of oxygen below which hypoxia is defined as the level of hypoxia tolerance is different in each organ and tissue [2]. Thus, hypoxia is rather a condition in which the whole body or specific tissues and organs are not sufficiently supplied with oxygen to meet the demand, and in which oxygen metabolism is suppressed [2]. The body has a physiological mechanism to adjust oxygen supply according to oxygen consumption. Although the absolute decrease in oxygen supply may be emphasized, the mismatch between oxygen supply and demand in organs and tissues (disordered tissue oxygen metabolism) should actually be considered as hypoxia in perioperative or critical care management $[3$,
Fig. 1 Dysregulation of oxygen metabolism and hypoxia-inducible factors (HIFs). Oxygen acquired from the lungs is transported through the entire body by the blood stream. Impaired oxygenation due to lung injury, impaired transport due to anemia or thrombosis, and impaired transfer of oxygen from blood to cells in tissues due to edema of tissue interstitium can lead to tissue hypoxia. In addition, impaired oxygen metabolism due to inhibition of oxygen utilization by drug-induced mitochondrial suppression has the same effect on the body as hypoxia. Such disturbances in oxygen metabolism affect the activity of HIFs, and this activation is affected by perioperative drugs, including anesthetics

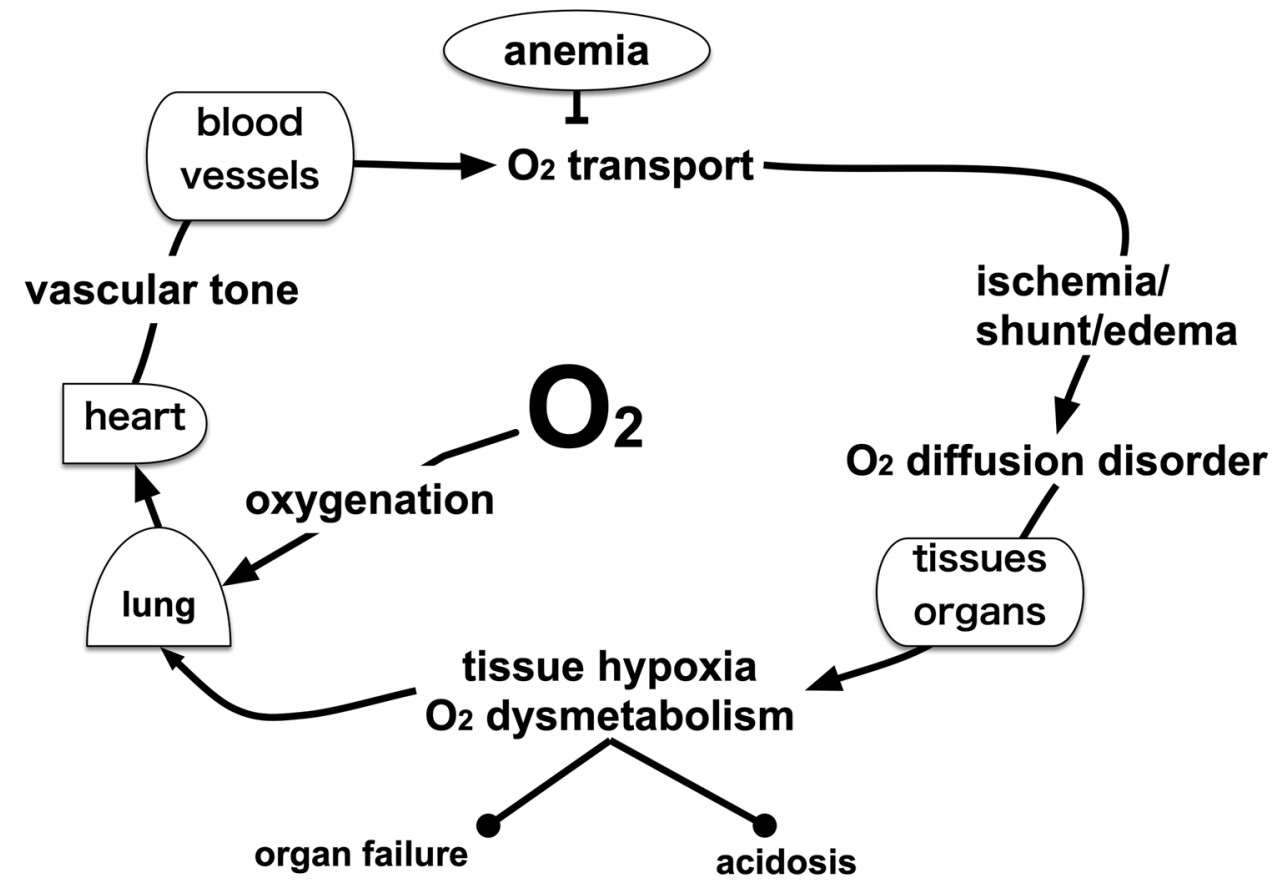


9]. Sepsis is a typical condition in which such a disorder of oxygen dynamism is observed. In septic shock, tissue hypoperfusion results from a decrease in blood pressure and the development of intravascular microthrombi, interstitial edema, and endothelial cell dysfunction $[14,15]$. In addition to these changes in oxygen delivery, various organs in the septic state are exposed to proinflammatory cytokines, and prolonged intracellular hypoxia leads to abnormal mitochondrial electron transport and reduced oxygen utilization efficiency. In this state, oxygen is utilized below the supply levels, even if a relatively large amount of it is supplied [16]. Hypoxia is not exclusively persistent. In fact, intermittent hypoxia may normally occur during surgical operation [17]. Compression of the liver or intestinal tract by surgical manipulation causes intermittent ischemia-reperfusion conditions [18]. Intermittent hypoxia accompanied by recurrent oxygenation is a typical generator of ROS, which causes an increase in the intracellular calcium ion $\left(\mathrm{Ca}^{2+}\right)$ concentration. The response of the body to continuous hypoxia is different from that to intermittent hypoxia [17, 19-21]. Patients with sleep apnea syndrome may experience intermittent episodes of hypoxemia more than 100 times/night $[22,23]$. Additionally, local intermittent hypoxia occurs upon surgical manipulation of intestine and use of tourniquet $[18,20]$. Studies on hypoxic response mechanisms or hypoxic sensing have been preceded by electrophysiological studies, including the involvement of ion channels [24-26]. The presence of markers of the hypoxic state in tissues and cells is highly useful. Although the research using classical biochemical methods has a long history, molecular biology methodologies were not applied until the 1990s. The transcription factor HIF-1 has been identified as an intracellular factor that is directly affected and activated by the decrease in oxygen concentration in cells. In this sense, the activation of HIF-1 can be considered a marker of hypoxia in cells and tissues.

\section{HIFs and the hypoxia-sensing mechanism}

The final process by which oxygen is supplied to cells is simple diffusion, but an anatomically complex higher multicellular organism has a specialized evolutionary mechanism to transport the necessary and sufficient oxygen to all the cells in the body [27]. The respiratory tract consists of the lungs, diaphragm, and other accessory muscles that provide the space for oxygen to bind to hemoglobin in red blood cells, and neuroepithelial cells that sense oxygen tension. The circulatory system consists of red blood cells as an oxygencarrying vehicle, the heart as a transport engine, and blood vessels as transport routes $[8,28,29]$. The proper development and maintenance of these systems require the coordinated expression of a few thousand genes. The transcription factor HIFs, whose activity is altered in an oxygen-tension dependent manner, are involved in the expression of many hypoxia-elicited genes [28, 29] (Fig. 2). HIF-1 increases the number of red blood cells through erythropoietin (EPO), regenerates blood vessels via vascular endothelial growth factors (VEGFs), and promotes glucose uptake via glucose transporter 1 . This can be interpreted as cells that are trying to become more adapted to hypoxic stress by mobilizing a
Fig. 2 Transcription factor networks and hypoxic response. Hypoxia-inducible factor-1 (HIF-1)-dependent gene response is an essential component of the hypoxia response in vivo and constitutes a network. The responses occur at the cellular, at the tissue and organ, and at the whole-body level. At each level, the hypoxia response appears as the sum of the reactions of individual cells. HIF-1 has been identified as a critical transcription factor in this network. HIF-1 is present in all nuclear cells, and its activation depends on the partial pressure of oxygen to which the cells are exposed, but its activation is also known to be modified by cell- and tissuespecific factors

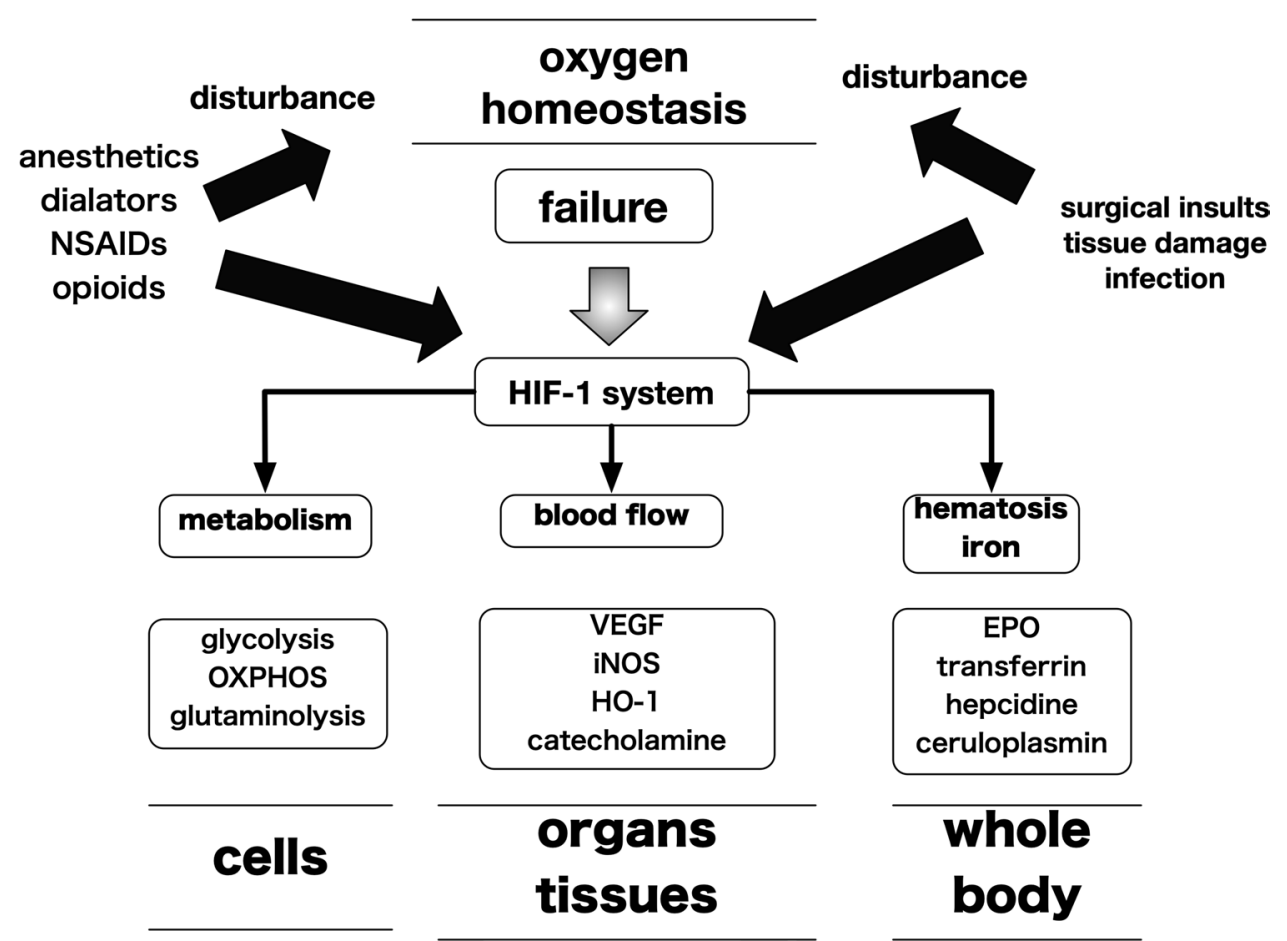


large number of genes through HIF-1. The results of a comprehensive gene expression study showed that more than 5,000 genes (at least $20 \%$ of all genes) were expressed in a hypoxia-inducible manner and regulated by HIF-1 [8, 30]. Thus, shifting the molecular biology of HIF into a new era of oxygen biology [7-9].

The functional transcription factor HIF-1 is composed of an $\alpha$ (HIF-1 $\alpha)$ and a $\beta$ (HIF-1 $\beta$ ) subunit linked by hydrophobic bonds; activated HIF-1 translocates to the cell nucleus and binds to the HIF-specific expression control region (hypoxia response element, HRE) of target genes to promote their expression [31, 32]. According to our study using human umbilical vein endothelial cells, 845 genes whose expression was induced more than 1.5 times under $1 \%$ oxygen partial pressure and 1072 genes whose expression was suppressed less than 1-1.5-fold of that were dependent on HIF-1 for $29 \%$ and $30 \%$ of all the transcripts, respectively [30, 33].

Several HIFs have been identified, including HIF-2 and HIF-3 in humans. In vivo, the roles of HIF subtypes in regulating activation are not identical. Redundancy exists, and in particular organization roles are mutually exclusive $[8,34]$.

The intracellular expression level, subcellular localization, and transcriptional activation of the HIF- $\alpha$ subunit are regulated by oxygen concentration.

Two classes of dioxygenases, which act as hydroxylase of HIF- $\alpha$ subunits, are critical regulators of HIF. These include three proline hydroxylase isozymes, proline hydroxylase domain (PHD) 1-3, and the asparagine residue hydroxylase factor inhibiting HIF (FIH)-1. These enzymes hydroxylate proline or asparagine residues requiring molecular oxygen, $\alpha$-ketoglutarate as the substrate, and divalent iron $\left(\mathrm{Fe}^{2+}\right)$ and ascorbic acid as the co-factors [35-42].

A scheme has been proposed in which the signal of a decrease in substrate oxygen tension is converted to a decrease in oxygenation, resulting in a reduced proportion of newly formed HIF- $1 \alpha$ that is hydroxylated, and consequent intracellular accumulation of HIF-1 $\alpha$ through inhibition of the ubiquitin-proteasome system (Fig. 3).

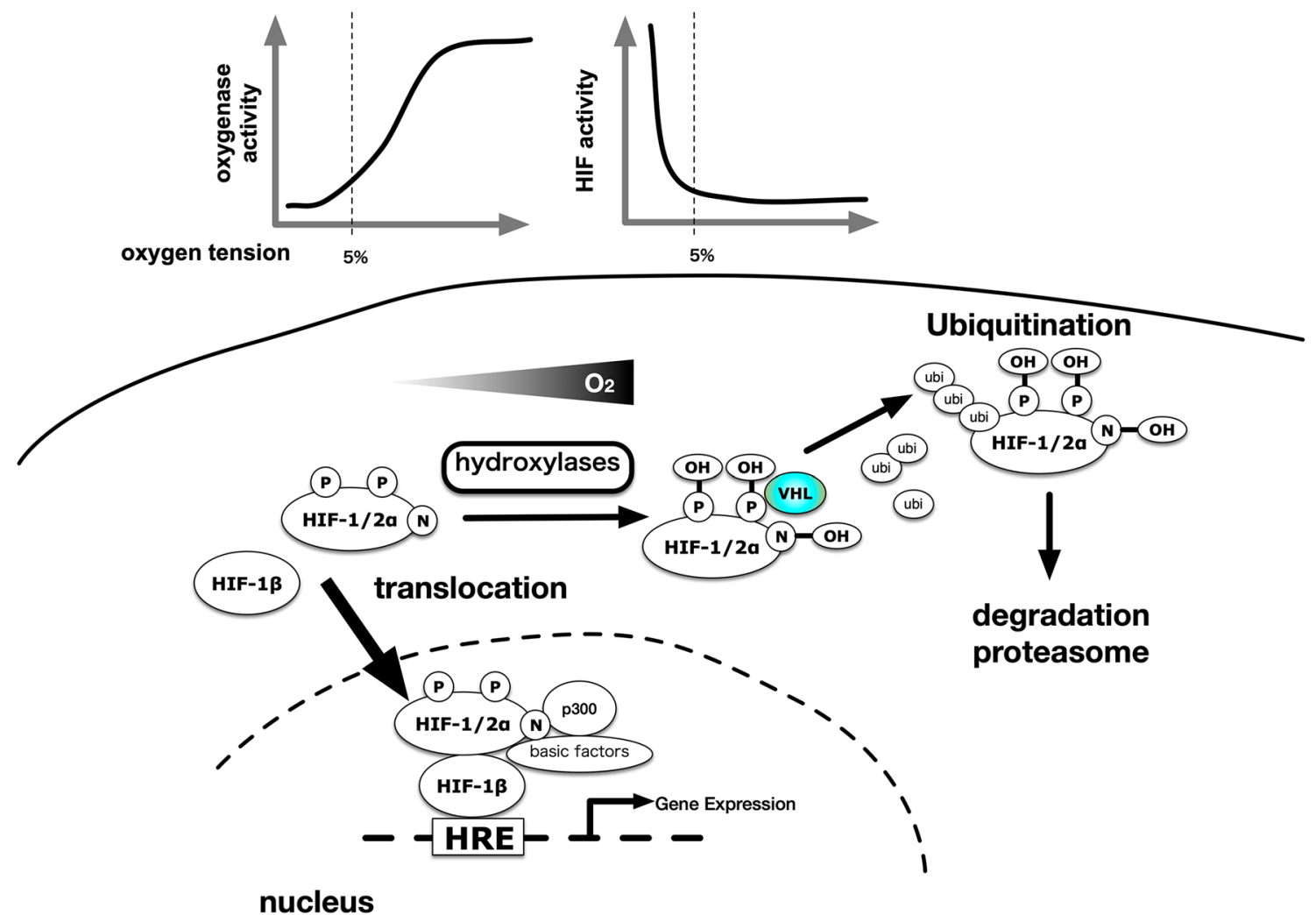

Fig. 3 The central dogma of hypoxia-induced gene responses. The main route of hypoxia-inducible factor-1 (HIF-1) activation is hydroxylation by the prolyl hydroxylase domain (PHD) protein, an HIF-1 $\alpha$ hydroxylase, and the factor inhibiting HIF-1 (FIH-1) protein. Oxygen is the substrate for this reaction. Reduced substrate concentration results in a reduced response, and HIF- $1 \alpha$ protein accumulates in the cell as an activated transcription factor, leading to downstream gene expression. The intracellular processes affecting this response may be regulators of HIF-1 activity independent of oxygen partial pressure. Additionally, certain intracellular signals lead to enhanced translation of HIF-1 $\alpha$, leading to activation of HIF-1 
This groundbreaking research was justifiably honored with the 2019 Nobel Prize in Physiology and Medicine jointly awarded to William G. Kaelin Jr, Sir Peter J. Ratcliffe, and Gregg L. Semenza for their discoveries of how cells sense and adapt to oxygen availability [8, 10, 34].

\section{Impact of perioperatively used drugs on cellular HIF-1 activity}

A series of studies has reported the effect of perioperatively used drugs on cellular hypoxia-induced gene expression mediated by HIFs (Fig. 4, Table 1).

\section{Volatile anesthetics}

Studies, mainly using immortalized cell lines, have reported that clinically relevant concentrations of isoflurane and sevofluorene promote intracellular accumulation of HIF- $1 \alpha$ protein under $20 \%$ oxygen [43-46]. These HIF-1 selective activations are accompanied by increased cell proliferation, inhibition of cell death, and increased motility which are particularly evident in cell lines derived from cancer cells. These changes are then accompanied by alterations in cancer suppressors that may be synergistic with volatile inhalant anesthetics and boost the malignancy of cancer cells.
In contrast, the seemingly conflicting results of studies in which halothane and isoflurane inhibit the expression of HIF- $1 \alpha$ protein under $1 \%$ oxygen coexist and warrant further investigation [47].

These results suggest that volatile anesthetics may modulate the activity of HIF in a manner dependent on the partial pressure of oxygen.

As for the activation of HIF-2, due to the limited reports available, it is not definitive at this moment.

\section{Intravenous anesthetics}

A series of studies investigated the effect of propofol on HIF activity. Propofol concentration of $25-100 \mu \mathrm{M}$ without emulsion inhibits activity and activation of HIF-1 [43, 48-51]. It is reported that propofol prevents isofluraneinduced HIF- $1 \alpha$ activation, and partially reduced cancer cell malignant activities in PC3 derived from prostate cancer. Plasma concentrations of propofol during anesthesia and sedation range between $2-(11 \mu \mathrm{M})$ and $5-\mu \mathrm{g} / \mathrm{mL}(27.5$ $\mu \mathrm{M})$ [52]. The concentration of propofol in tissues of $20 \mathrm{mg} /$ $\mathrm{kg} / \mathrm{h}$ propofol-treated rats could reach $200 \mu \mathrm{M}$ under certain conditions. Although the mechanism of suppression is not yet fully understood, some studies have shown that propofol suppresses mitochondrial oxygen metabolism [53, 54].
Fig. 4 Impact of perioperative drugs on the regulation of hypoxia-inducible factor (HIF) activity. The effects of perioperative medicines, including anesthetics, narcotics, and vasoactive drugs on HIF-1 activity, are illustrated. Perioperative medications such as drugs that promote activation and drugs that inhibit activation exert various effects on HIF-1 activity

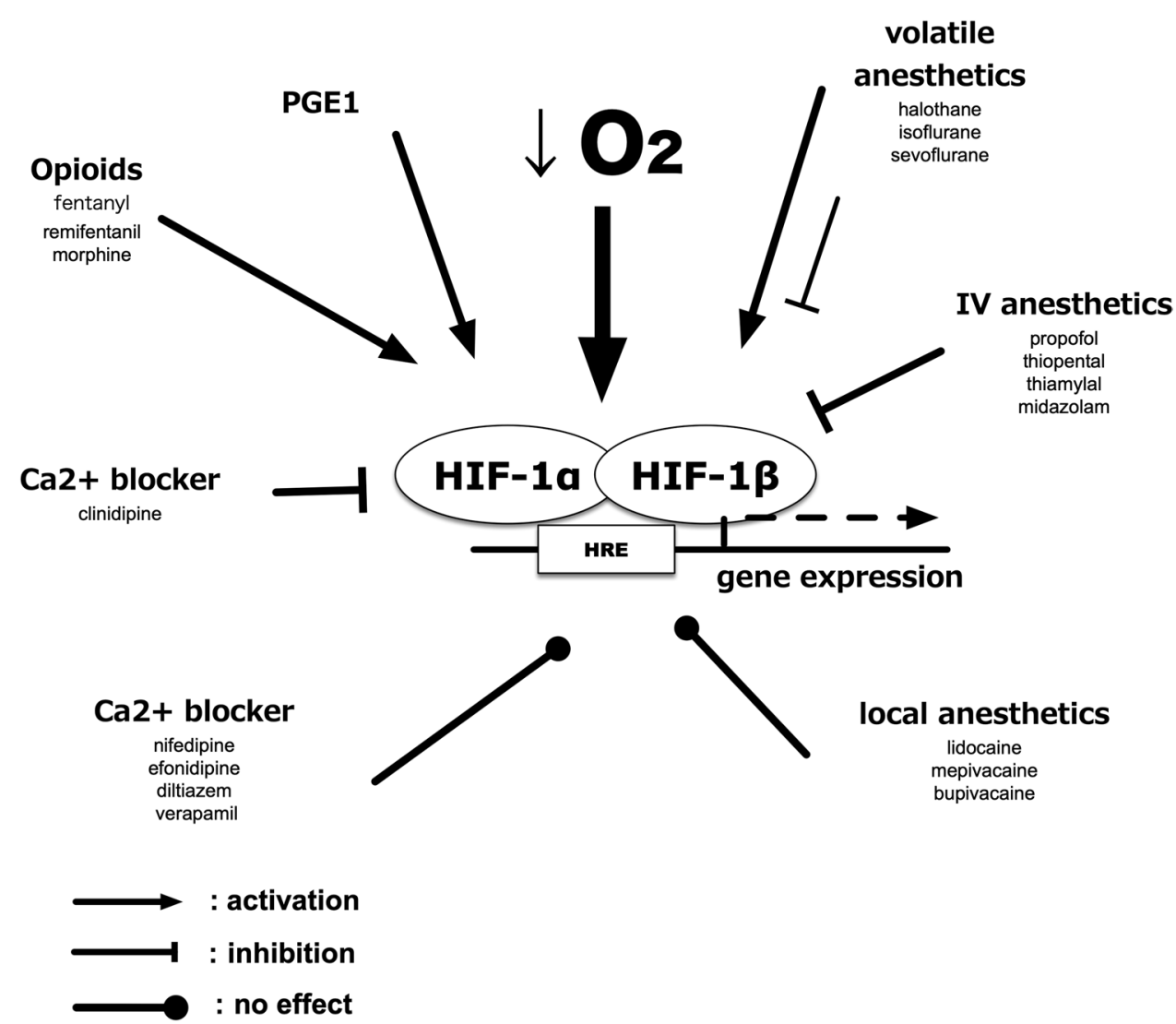


Table 1 Effect of perioperative drugs on HIF activation

\begin{tabular}{llll}
\hline & HIF-1 activity & \\
\cline { 2 - 3 } & Normoxia & Hypoxia & References \\
\hline Volatile anesthetics & & & \\
Halothane & $\rightarrow$ & $\downarrow$ & {$[47]$} \\
Isoflurane & $\uparrow, \rightarrow$ & $\downarrow$ & {$[43-46,73,74,104]$} \\
Sevoflurane & $\uparrow, \rightarrow$ & $\downarrow$ & {$[44,46,73,74,104]$} \\
Intravenous anesthetics & & & \\
Propofol & $\downarrow$ & $\downarrow$ & {$[48,49]$} \\
Thiopental & $\rightarrow$ & $\downarrow$ & {$[55]$} \\
Thiamylal & $\rightarrow$ & $\downarrow$ & {$[55]$} \\
Midazolam & $\rightarrow$ & $\downarrow$ & {$[57,62]$} \\
Ketamine & $\rightarrow$ & N.D & {$[58]$} \\
Dexmedetomidine & $\uparrow$ & N.D & {$[59-61]$} \\
Nitrates & & & \\
Nitroglycerin & $\rightarrow$ & $\rightarrow$ & {$[70]$} \\
Isosorbide & $\rightarrow$ & $\downarrow$ & {$[70]$} \\
Nitroprusside & $\downarrow$ & $\rightarrow$ & {$[70]$} \\
Calcium blocker & & $\rightarrow$ & {$[672]$} \\
Nicardipine & $\rightarrow$ & $\rightarrow$ & {$[72]$} \\
Cilnidipine & $\downarrow$ & $\downarrow$ & {$[72]$} \\
Verapamil & $\rightarrow$ & $\rightarrow$ & {$[72]$} \\
Diltiazem & $\rightarrow$ & $\rightarrow$ & {$[72]$} \\
Local anesthetics & & & {$[68,69]$} \\
Lidocaine & $\rightarrow$ & $\rightarrow$ & {$[65]$} \\
Bupivacaine & $\rightarrow$ & $\rightarrow$ & {$[68]$} \\
Opioids & $\uparrow$ & $\rightarrow$ & \\
Fentanyl & $\uparrow$ & $\rightarrow$ & {$[65]$} \\
Remifentanil & $\uparrow$ & & \\
Morphine & & & \\
PGE1 & & & \\
\hline
\end{tabular}

Ultra-short-acting barbiturates, including thiopental and thiamylal, also suppress HIF-1 activity [55]. If both proteinbound and unbound forms are included, the peak plasma concentration of thiopental after induction of anesthesia would be in the range of 100-300 $\mu \mathrm{M}$ [56]. As the study was performed in media containing $10 \%$ serum, the concentration of thiopental and thiamylal in the study is clinically relevant [55].

Midazolam also significantly reduces the hypoxiainduced up-regulation of EPO, in BALB/c mouse brains and primary cultured astrocytes, and suppresses EPO expression in the fetal brain of mice. However, this anesthetic does not affect the total amount of HIF proteins but significantly inhibits the nuclear expression of HIF- $1 \alpha$ and HIF- $2 \alpha$. These results, therefore, demonstrate the suppressive effects of midazolam on the hypoxia-induced up-regulation of EPO both in vivo and in vitro [57].
Repeated administration of ketamine induces hippocampal neurodegeneration and long-term cognitive impairment via the ROS/HIF-1 $\alpha$ pathway in developing rats [58].

The impact of dexmedetomidine (DEX) on the activity of HIF-1 is currently debated. Although some studies reported that DEX activates HIF-1 in an $\alpha 2$ receptor-dependent manner $[59,60]$, others reported that DEX activates HIF-1 in an I2 imidazoline receptor-dependent manner [60, 61]. Wang et al. demonstrated that midazolam possessed antitumorigenic properties partly mediated by the peripheral benzodiazepine receptor, whereas dexmedetomidine promoted cancer cell survival through signaling via the $\alpha 2$-adrenoceptor in lung carcinoma (A549 cells) and neuroglioma cells (H4 cells) [62]. It is reported that the clinical concentrations for dexmedetomidine range from 0.2 to $2 \mathrm{ng} / \mathrm{mL}(1-10 \mathrm{nM})$ within the range of this study [63]. In contrast, clinical concentrations of midazolam range from 100 to $200 \mathrm{ng} / \mathrm{mL}$ (less than $1 \mu \mathrm{M})$; the concentrations used here are greater $(25-400$ $\mu \mathrm{M})$ than those in the clinical setting [64].

\section{Opioids}

The effect of fentanyl and other opioids on HIF-1 activity was also investigated in established cell lines [65]. Cells were exposed to fentanyl, and expression and activity of HIF-1 proteins were examined. HIF-1-dependent gene expression was investigated by qRT-PCR. A 10-nM concentration of fentanyl and other opioids, including $1 \mu \mathrm{M}$ morphine and $4 \mu \mathrm{M}$ remifentanil, induced expression of HIF-1 $\alpha$ and HIF-1 target genes in an opioid receptor-dependent manner in SH-SY5Y cells, with activity peaking at $24 \mathrm{~h}$. In contrast, there are reports that morphine inhibits the activation of HIF-1 [66]. Interestingly, fentanyl did not augment HIF- $1 \alpha$ expression elicited by hypoxia. HIF- $1 \alpha$ stabilization assays and experiments with cycloheximide revealed that fentanyl increased translation of HIF- $1 \alpha$ mRNA but did not stabilize HIF- $1 \alpha$ protein. There are reports of no effect on the activation of HIF-2 and reports that it causes activation by opioid ligands $[65,67]$.

As the effect site concentrations of fentanyl and remifentanil are reported to be $5 \mathrm{ng} / \mathrm{mL}(15 \mathrm{nM})$ and $10 \mathrm{ng} / \mathrm{mL}$ ( 25 $\mathrm{nM}$ ), respectively, $10 \mathrm{nM}$ fentanyl and $4 \mathrm{nM}$ remifenanil fall into this range in terms of concentration.

Fentanyl $(400 \mu \mathrm{g} / \mathrm{kg})$ administered intraperitoneally to mice increased brain glucose transporter 1 (GLUT-1) and VEGF mRNA levels and concomitant use of naloxone (2.0 $\mathrm{mg} / \mathrm{kg}$ ) suppressed this induction within $12 \mathrm{~h}$. However, the study did not provide the experimental results of HIF- $1 \alpha$ protein expression. 


\section{Local anesthetics}

The local anesthetics lidocaine and bupivacaine do not affect HIF-1-dependent cellular hypoxia-induced gene responses. The question to be considered when considering the effects of local anesthetics is whether they are local or systemic $[68,69]$.

No imposed effects on hypoxia-induced HIF-1 activation were observed when placed in $0.1 \%$ equivalent of lidocaine and $0.025 \%$ equivalent of bupivacaine. In contrast, there are reports that lidocaine suppresses the mitochondrial electron transfer system and thus inhibits the metabolism of oxygen in cells [68].

\section{Other perioperative drugs}

Nitric oxide (NO) mediates a variety of biological effects, including relaxation of blood vessels and cytotoxicity of activated macrophages. Several studies investigated the effects of NO on hypoxic signaling using NO donors as reagents. The results of studies using pharmacological reagents are omitted here. However, although there are studies that have examined the effects of nitrite preparations used in clinical practice, no studies have examined the effects of inhaled NO gas on HIF-1. Among the three clinically used nitrates nitroglycerin (NTG), isosorbide dinitrate (ISDN), and sodium nitroprusside (SNP), only SNP inhibits HIF-1 activation in cellular response to hypoxia. In contrast, NTG or ISDN does not affect HIF-1 activity. However, SNP blocks the accumulation and transcriptional activation of HIF- $1 \alpha$ via a mechanism that is not dependent on either NO or soluble guanylate cyclase [70].

Prostaglandin E1 (PGE1), known pharmaceutically as alprostadil, has vasodilatory properties and is used widely in various clinical settings. The mechanism by which PGE1 induces HIF-1 activation and VEGF gene expression has been investigated in human aortic smooth muscle cells (HASMCs) and human umbilical vein endothelial cells (HUVECs), both vascular-derived cells. HIF- $1 \alpha$ protein and HIF-1-downstream genes are expressed at low levels under $20 \%$ oxygen. However, in both HUVECs and HASMC treatment, they show higher expression in response to PGE1 under $20 \%$ oxygen than $1 \%$ oxygen, increasing in a dose- and time-dependent manner. Studies using EP receptor-specific agonists and antagonists revealed that EP1 and EP3 are critical to PGE1-induced HIF-1 activation. In vitro, vascular permeability assays using HUVECs indicated that PGE1 increases vascular permeability in HUVECs. Thus, PGE1 induces HIF-1 $\alpha$ expression and HIF-1 activation under nonhypoxic conditions. This evidence also shows that the activity of multiple signal transduction pathways downstream of EP1 and EP3 receptors are required for HIF-1 activation [71].
Calcium ion $\left(\mathrm{Ca}^{2+}\right)$ is one of the most important second messengers of cellular signal transduction, including hypoxia-elicited signals. Thus, the effects of the L-type calcium channel blockers such as nifedipine, efonidipine cilnidipine, diltiazem, and verapamil, on the activity of HIF-1, were investigated. Using the lung carcinoma cell line A549 cells, human aortic smooth muscle cells, and human umbilical vein endothelial cells, $30 \mu \mathrm{M}$ cilnidipine-which is lower than clinically relevant doses $(10 \mu \mathrm{g} / \mathrm{L})$ exclusively suppressed HIF-1 activity and the expressions of downstream genes in a cell-type-specific manner. Cilnidipine blocked the synthesis of the HIF- $1 \alpha$ protein not by affecting the activity of the intracellular hypoxia-sensing element prolyl hydroxylases but the inhibiting activity of Akt and mitogen-activated protein kinase and that the inhibition is not dependent on the effect on calcium homeostasis [72].

\section{Impact of perioperatively used drugs on systemic HIF-1 activity}

To date, researchers have mainly examined the effects of perioperatively used drugs on HIF-1 activity. Although there is a possibility in which the HIF activity of the organism is adjusted by the drug, which the anesthesiologist uses daily is indicated, the examination of effects on a clinical outcome such as patient prognosis is not precise at present. Because of the dynamic changes in the oxygen environment in the perioperative and critical care areas, understanding the involvement of HIF is of great interest from physiological, pathophysiological, and pharmacological perspectives. As in vivo studies using genetically modified animals have only recently begun, the following sections describe the effects of anesthetics on systemic HIF-1 activity as revealed to date.

\section{EPO expression in response to hypoxemia and anemia}

Evidence obtained from in vitro studies cannot always be applied in in-vivo settings. Experiments with mice from our previous studies provide examples showing the effects of anemia on the volatile anesthetic [73, 74]. When 9-week-old C57BL mice were exposed to $10 \%$ oxygen, their $\mathrm{SpO}_{2}$ was approximately $82 \%$ (hypoxemic group). However, $200 \mu \mathrm{L}$ blood loss from the orbital vein decreases the hematocrit from 44 to 33\% (anemic group). In this condition, plasma EPO levels determined $3 \mathrm{~h}$ later by ELISA were $50 \mathrm{pg} / \mathrm{mL}$, $1000 \mathrm{pg} / \mathrm{mL}$, and $1400 \mathrm{pg} / \mathrm{mL}$ in control, hypoxemia, and anemia group, respectively. Therefore, the anemic state is very strong inducer of the hypoxia-driven gene response of the organism.

In mice exposed to hypoxic conditions at an oxygen partial pressure of $10 \%$, EPO expression levels increased in the brain and kidney [73, 74]. Moreover, while in the brain the expression of HIF- $2 \alpha$ increases, HIF- $1 \alpha$ remains 
Fig. 5 Regulatory mechanism of EPO and iron metabolismrelated genes in cells. HIF-PH inhibitors are already being prescribed in clinical practice for the treatment of renal anemia. The target organs of HIF-PH inhibitors include kidney, liver, and intestinal epithelial cells. HIF-2 rather than HIF-1 acts as a major factor in ameliorating anemia by inducing the expression of erythropoietic growth factors, including EPO, and various genes associated with improved iron metabolism. It is known that HIF-2 induces the expression of EPO in REP cells and inhibits the expression of hepcidin in the liver. $E P O$ erythropoietin, $H A M P$ : hepcidin, $C Y B R D 1$ Dcytb, $T F$ transferin, FURIN furin

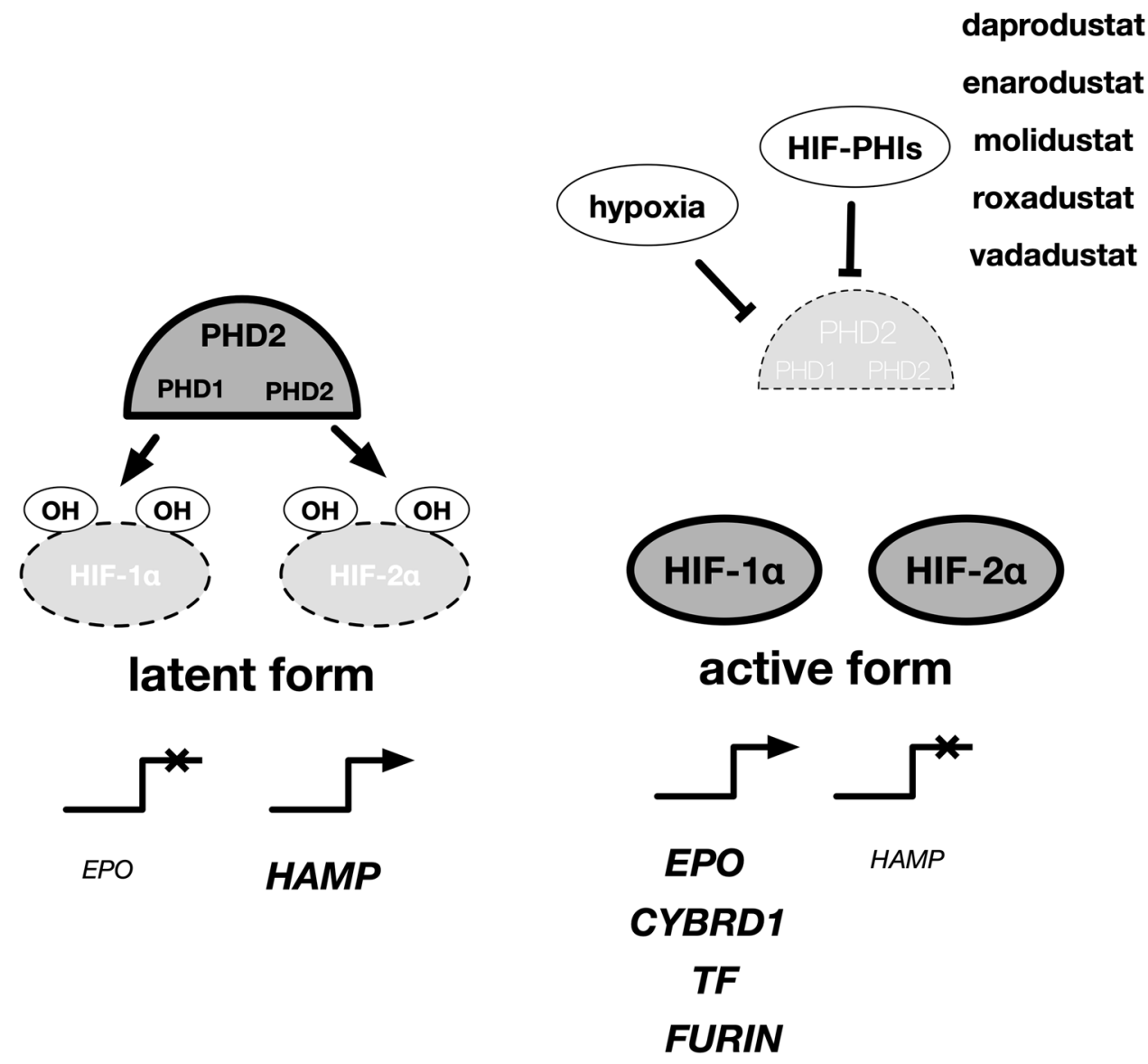

constitutively expressed in this organ, and no increase was observed under $10 \%$ partial pressure of inhaled oxygen. The study also showed that isoflurane selectively inhibits the induction of EPO expression and the induction of HIF-2 $\alpha$ expression in the brain.

In the past, erythropoiesis-stimulating agents (ESAs), such as recombinant EPO, were used as the main treatment for renal anemia. However as they are injectable drugs, the risk of infection and the physical burden on patients are high. In November of 2019, HIF-proline hydroxylase (HIF$\mathrm{PH}$ ) inhibitors were launched for the treatment of chronic kidney disease. Four drugs-Roxadustat, Daprodustat, Vadadustat, Molidustat, and Enarodustat-are currently available in Japan (Fig. 5). HIF-PH inhibitors inhibit a regulatory enzyme of HIF, thereby inhibiting the degradation of the transcription factor HIF- $\alpha$ and activating the HIF pathway. As a result, similar to the erythropoietic response that occurs when the body is exposed to hypoxia, erythropoiesis is stimulated even in normoxic conditions, thus potentially improving anemia by increasing the red blood cell count and hemoglobin concentration [75-79]. In principle, this leads to the activation of HIF-1 and HIF-2 in cells throughout the body; thus,patients consuming this drug in perioperative management may require special care [80]. In addition, even if the patient does not have renal anemia, there is a possibility of prescribing a drug for hematopoiesis prior to or after surgery. The effect of anesthetics on HIF activation by these HIF-PH inhibitors may also be an issue that warrants further investigation.

\section{Lactate and hypoxic response}

As stated in the diagnostic criteria for septic shock in "International Consensus Definition of Sepsis and Septic Shock, 3rd Edition (Sepsis -3$)$ ", high serum lactate $(>2 \mathrm{mmol} / \mathrm{L})$ is positively correlated with patient prognosis in critical care [81, 82].

There is a dogma that defined lactic acidosis as decreased tissue oxygen supply. However, this concept has been challenged, and it is now dominated by the view that "Elevated lactate levels do not necessarily indicate tissue hypoperfusion; other measures may be used as needed" [83].

This approach is applied to the understanding of the pathological state known as propofol infusion syndrome [84, 85]. Propofol has been shown to impair mitochondrial respiratory chain and fatty acid oxidation under certain conditions, leading to cellular damage, increased anaerobic metabolism, 
and acidosis. The effects of propofol on cells using an extracellular flux analyzer that can measure-in real time- the oxygen consumption rate (OCR) and the extracellular $\mathrm{pH}$ change (ECAR), which is thought to reflect lactate production was reported. HIF-1-dependent metabolic reprogramming switch from oxidative phosphorylation to glycolysis occurred after $2 \mathrm{~h}$ of hypoxic exposure [53]. In other words, OCR is suppressed and ECAR-a surrogate marker for lactate production-is increased. In contrast, propofol, which is used for anesthesia and sedation, stimulates lactate production by inhibiting cellular oxygen consumption at a concentration of $25 \mu \mathrm{M}$ within $4 \mathrm{~h}$ [53]. When co-administered with metformin, propofol exerts an inhibitory effect on oxygen consumption even at a concentration of $12.5 \mu \mathrm{M}$. Metformin, a biguanide antidiabetic drug, has mitochondrial inhibition with lactic acidosis as its side effect. These experimental facts indicate that lactate is a substance produced in response to modification of mitochondrial function. This is an example of how drug-induced mitochondrial dysfunction promotes lactate production. In addition, clinical concentrations of propofol can easily induce a shift in the metabolic mode of the cell if/when mitochondrial function is inhibited. There are several issues to keep in mind when interpreting these results for direct clinical application: these results are from experiments using cultured cells, and in clinical practice, not only blood but also tissue accumulation of propofol should be important. Several reports indicate that $12.5-25 \mu \mathrm{M}$ of propofol is clinically relevant, but in clinical practice, not only blood but also tissue accumulation of propofol should be important $[52,86]$. Collectively, these experimental findings indicate that lactate is a product of altered mitochondrial function. Drug-induced mitochondrial damage is an example of lactic acid production. Together, these results can explain part of the pathophysiology of PRIS [87], in which propofol increases lactate production by shifting metabolism from the mitochondrial to the glycolytic system in a time- and concentration-dependent manner.

\section{Cancer metastasis and recurrence}

Anesthesiology has extended its perspective from the academic field of surgical anesthesia to perioperative patient management [88-91]. Examining the impact of anesthesia on the long-term prognosis of patients is the challenge that anesthesiologists have faced in recent years. Typical examples include the effects of anesthetics on cancer metastasis and recurrence [92-94]. When considering these long-term prognostic issues, the effects of anesthetics on immune function, the basic system of biological response, cannot be ignored [34, 88, 95-98].Several reports describe that isoflurane induces HIF proteins and thereby enhances malignant phenotypes in vitro [43, 45, 99]. HIF-1 was originally cloned as a driver of EPO expression; however, shortly after that, it was reportedly associated with tumor grade in various cancers $[32,100]$. Indeed, HIFs are now well known as critical regulators of cancer hallmarks, including sustained proliferative signaling, evasion of growth suppressors, resistance to cell death, replicative immortality, angiogenesis, invasion, and metastasis. Moreover, tumor suppressors such as TP53 and PTEN also regulate HIFs [101-103]. Another striking example of the physiological significance of HIFs is von Hippel-Lindau (VHL) disease, a hereditary cancer syndrome predisposing individuals to highly angiogenic tumors, wherein the constitutive overexpression of VEGF and GLUT-1 can be rectified by functional VHL protein. VHL is a tumor suppressor that targets HIFs for degradation. A study investigating the effect of isoflurane on growth and migration of derivatives of the renal cell line RCC4 that express (RCC-VHL) or do not express (RCC4-EV) VHL showed that HIFs significantly influence cancer cell growth and migration; however, isoflurane does not affect HIFdependent phenotypes [104, 105].

Recently acquired data raised the possibility of the anesthetic technique and conduct of the perioperative period as a possible contributory factor in the growth of the primary tumor and possible recurrence. Preexisting 'micrometastasis' also is a concern following resection of the primary tumor. Whether the extruded cancer cells left in the body will remount an attack depends on the tumor microenvironment during the perioperative period.

It is reported that sevoflurane enhanced proliferation, migration, and invasion of immortalized cervical cancer cells, which was likely associated with increasing histone deacetylase 6 expression caused by phosphatidylinositol-3 kinase (PI3K)/AKT- and ERK1/2-signaling pathway activation [106] and that sevoflurane may have different effects on the metastatic potential and chemosensitivity of different tumor types [107]. Thus, it has been pointed out that anesthesia, including the choice of anesthetic, may have a significant impact on the prognosis of cancer patients, forming an academic field called onco-anesthesia [108-111].

Cancer cells reprogram their metabolic system to favor their own cell proliferation, actively utilizing the glycolytic system, which is less efficient in producing ATP even in the presence of oxygen, to enhance glucose uptake and lactate production (Warburg effect) $[112,113]$. Thus, it has become clear that immunity and metabolism are deeply intertwined, and the importance of metabolic control has been recognized. Although cancer immunotherapy has been recognized by the success of immune checkpoint inhibitors, it is essential to use metabolic control in combination. Taken together, these are important targets for cancer immunotherapy and in future, cancer immunotherapy and immunometabolism will have important parts to play in onco-anesthesia field. 


\section{Involvement in immunity and SARS-CoV-2 infection}

There is a growing body of research showing that the oxygen environment of the immune field has a critical impact on immune function and the function of immunocompetent cells.

In this section, in addition to the relationship between immune function and HIF, we would like to describe the relationship between HIF and SARS-CoV-2 infection, or COVID-19, which is still raging since 2019 [114].

The role of oxygen metabolism in the regulation of inflammation and immune response has received much attention. Factors such as cytokines and chemokines, and physical stimuli such as heat and tissue destruction induce ROS and generate oxidative stress, while impaired blood vessels, impaired blood flow, increased oxygen consumption by infiltrating cells, and impaired oxygen diffusion due to edema reduce the oxygen concentration in tissues. Inflammatory cells, which work "in the field" of inflammation, adapt to these changes in the oxygen environment to maintain cellular functions and contribute to biological defense and homeostasis.

It has been reported that prostaglandin E1/E2, a mediator of inflammation, also causes HIF-1 activation in an EP receptor-dependent manner. Proinflammatory substances such as endotoxins (lipopolysaccharide; LPS) cause activation of HIF-1 using a receptor-mediated signaling pathway into the cell. The signal from the receptor activates PI3K, which transmits the signal to mTOR (mammalian target of rapamycin) and S6 kinase via Akt, resulting in an increased translation of HIF- $1 \alpha$ protein from mRNA [115]. HIF- $1 \alpha$ protein accumulates in the cells, resulting in the activation of HIF-1. Parallel to this pathway, MAPK-mediated up-regulation of HIF- $1 \alpha$ translation has also been reported, and inflammatory cytokines such as TNF- $\alpha$ and IL- $1 \beta$ also cause the up-regulation HIF- $1 \alpha$ translation through the PI3K-AktmTOR signaling pathway. In this pathway, ROS and NO (nitric oxide), which are promoted by TNF- $\alpha$, act as second messengers and simultaneously activate NF- $\kappa$ B. Conversely, transcriptional induction of HIF- $1 \alpha$ mRNA is induced by TNF- $\alpha$ and LPS in a ROS- and NF- $\kappa \mathrm{B}-$ dependent manner. In other words, inflammatory cytokines and HIFs act in an interdependent manner and are involved in the development of inflammatory responses [116].

In addition to activation by these cytokines, it has been reported that infectious pathogens can activate HIF-1. Bacterial infections by Staphylococcus aureus, Pseudomonas aeruginosa, and Salmonella induce HIF-1 activation in macrophages and neutrophils, and parasitic infections by Toxoplasma induce HIF-1 activation through the intracellular stabilization of HIF- $1 \alpha$ protein in fibroblasts. Bacterial infections contribute to the activation of HIF-1 through other pathways. Respiratory syncytial virus infection of the airway epithelium triggers HIF-1 activation through a NO-dependent mechanism $[8,116]$. These activations are thought to result in the release of VEGF, leading to clinical symptoms such as airway edema. The effect of anesthetics on such innate immunity warrants further investigation.

Evidence that surgical stress and anesthesia affect a patients' immune system has been provided by conventional research. One explanation is the vaccination timing restriction that is carried out in the operation room [117, 118]. There is a consensus that anesthesia during surgical operations can affect immune function as well as safety and effectiveness of immunizations [119-121]. However, there is insufficient scientific evidence on the relationship between the immune response to the vaccine antigen and anesthesia [117]. When considering these long-term prognostic effects from a molecular biology perspective, the common question is what changes in cells and systems in vivo are caused by anesthesia in a relatively short period when exposed to anesthetics, and what is the underlying molecular mechanism. In other words, the transient effects of anesthesia can be reinterpreted as the question of how to create a situation in which one has a long-term "memory".

Metabolic regulation plays an essential role in the memory of the immune system. For example, mTOR signaling enhances glycolysis in effector T cells [122], whereas AMPK signaling increases oxidative phosphorylation in mitochondria following fatty acid oxidation in regulatory $\mathrm{T}$ cells (Treg) [123, 124]. HIF-1 plays a significant role in metabolic regulation [124-126]. The conversion to predominant glycolysis from oxidative phosphorylation occurs with the activation of neutrophils and macrophage in a HIF-1- dependent manner [127-129]. Pathogens and foreign substances that have overcome innate immunity induce acquired immunity centered on antigen-specific T and B cells [129-131]. Nonetheless, numerous reports show that metabolism regulation through HIF-1 plays a central role in the functional expression of T cells and B cells $[132,133]$. Compared to studies of the effects of anesthetics on the nervous and endocrine systems, the study of the effects on the immune system has accumulated phenomenology, but the molecular mechanisms remain largely unknown.

The COVID-19 pandemic caused by SARS-CoV-2 infection is still sweeping the world.

The excessive inflammatory response induced by SARSCoV-2 is correlated with the severity of the infected patients, and the resulting acute respiratory distress syndrome (ARDS) is a major cause of death. Acute lung injury associated with sepsis and ARDS may be familiar to the readers of the Journal of Anesthesia. In addition, viral infections can cause cytokine release syndrome or cytokine storm.

The basis for this "peculiar phenomenon" of COVID19 is the patient's hypoxemia. Although the hypoxemia is severe according to objective tests, it is not accompanied 
by subjective symptoms such as dyspnea (silent), which has attracted attention as the silent hypoxemia syndrome, also known as happy hypoxia $[134,135]$.

The viral genomic RNA of SARS-CoV-2 is surrounded by an envelope consisting of a lipid bilayer and outer membrane proteins. The $S$ protein is cleaved into $S 1$ and $S 2$ by a protease (proteolytic enzyme) from human cells, assumed to be Furin. S1 then binds to the receptor, ACE2 receptor. The other fragment, S2, is cleaved by TMPRSS2, a human cell surface serine protease, resulting in membrane fusion. A line of studies indicate that furin is upregulated along with ACE2 by HIF-1. This fact strongly suggests that the oxygen environment of the organism is involved in the infectivity of SARS-CoV-2 to cells through the regulation of HIF-1 activation.

It is reported that deep vein thrombosis occurred in $7 / 12$ (58\%) and pulmonary embolism was the direct cause of death in $4 / 12(30 \%)$ of patients in 12 consecutive autopsies with COVID-19 [136]. Thrombi in the microcirculatory system, such as small arteries, small veins, and capillaries, can cause damage to vital organs. Initially, it was thought that the multi-organ damage associated with thrombus formation in the microcirculatory system was similar to disseminated intravascular coagulation (DIC), which is often seen during bacterial infection. Disorders of the microcirculatory system often result in altered consciousness and renal impairment. These symptoms are often seen in thrombotic microangiopathy (TMA), suggesting the existence of a partially common developmental mechanism. A line of studies indicates that hypoxemia is one of the important contributing factors for coagulopathy. It is proposed that hypoxia induces Early Growth Response 1, which in turn regulate thrombus formation [137, 138]. Moreover, HIFs or HIF targeted genes induces prothrombotic factors like PAI-1 and tissue factors, while antithrombotic factors like thrombomodulin, Protein $S$ and TFPI [139-143]. However, the exact role of these pathways is yet to be elucidated in COVID-19 pathology. A detailed study showing an association between tissue/ serum HIF levels with various prothrombotic and antithrombotic factors in COVID-19 patients is required to substantiate our theory.

As explained in the previous section, the HIF system is deeply involved in regulating the delicate balance of the immune system.

The pathophysiology of COVID-19, the SARS-CoV-2 infection, shows that the in vivo oxygen environment plays a major role through the activation of HIF [144, 145].

\section{Conclusion}

Hypoxia biology was comprehensively reviewed in terms of HIF activation regulation, anesthesiology, and intensive care. While oxygen homeostasis is essential for survival, importantly, hypoxia also plays a critical role in the pathogenesis of perioperative morbidity and mortality. Investigating the molecular mechanisms of oxygen homeostasis therefore represents an effort to delineate fundamental aspects of human physiology. A better understanding of oxygen biology may also provide new insights about, and potentially new therapeutic approaches to, the most critical public health problems of the present day including COVID-19. The knowledge gained from the development of real-time monitoring methods for organ-level oxygen metabolism will lead to the development of perioperative medicine. Finally, HIF is a factor that is activated not simply by hypoxia, but broadly by modulation of oxygen metabolism, and may thus be a target for intervention in overcoming various oxygen metabolic imbalances (Table 1).

\section{Glossary}

Transcription factor

Transcription factors are a group of proteins that bind specifically to DNA. Transcription is initiated by the binding basic transcription factors and RNA polymerase (RNA synthetase) to promoter regions on DNA. The process of transcribing genetic information from DNA to RNA is promoted or conversely, repressed.

Epigenome While the DNA sequence is called the genome, the modifications made to the genome are known as epigenome. The epigenome is acquired and is subject to change. Methylation and hydroxymethylation of DNA and modification of histone proteins (methylation, acetylation, phosphorylation, etc.) are the main known modifications.

Innate and acquired immunity
With the immune system is split into two main classes: innate immunity and acquired immunity. Innate immunity is the first line of defense against 
pathogens and is responsible for eliminating them before they can infect the host. When this defense system is breached, acquired immunity is triggered.

Acknowledgements This work was supported by the Japan Society for the Promotion of Science KAKENHI, Grants JP20H03776. This work was also supported by a research grant from the Kansai Medical University (KMU) research consortium, the branding program as a worldleading research university on intractable immune and allergic diseases from MEXT Japan, and a research grant from Katano Kai. We would like to thank Editage (www.editage.jp) for English language editing.

\section{References}

1. Williams $\mathrm{AJ} . \mathrm{ABC}$ of oxygen: assessing and interpreting arterial blood gases and acid-base balance. BMJ. 1998;317:1213-6.

2. Evans TW, Smithies M. ABC of intensive care: organ dysfunction. BMJ. 1999;318:1606-9.

3. Martin DS, Grocott MP. Oxygen therapy in critical illness: precise control of arterial oxygenation and permissive hypoxemia. Crit Care Med. 2013;41:423-32.

4. Molnar Z, Nemeth M. Monitoring of tissue oxygenation: an everyday clinical challenge. Front Med (Lausanne). 2017;4:247.

5. Sakka SG. Hemodynamic monitoring in the critically ill patient current status and perspective. Front Med (Lausanne). 2015;2:44.

6. West JB. Joseph Priestley, oxygen, and the enlightenment. Am J Physiol Lung Cell Mol Physiol. 2014;306:L111-9.

7. West JB. Physiological effects of chronic hypoxia. N Engl J Med. 2017;376:1965-71

8. Hirota K. Basic biology of hypoxic responses mediated by the transcription factor HIFS and its implication for medicine. Biomedicines. 2020;8:32.

9. Hirota K. Hypoxia-inducible factor 1, a master transcription factor of cellular hypoxic gene expression. J Anesth. 2002;16:150-9.

10. Fandrey J, Schodel J, Eckardt KU, Katschinski DM, Wenger RH. Now a Nobel gas: oxygen. Pflug Arch. 2019;471:1343-58.

11. Bateman NT, Leach RM. ABC of oxygen. Acute oxygen therapy. BMJ. 1998;317:798-801.

12. Harms FA, Bodmer SI, Raat NJ, Mik EG. Non-invasive monitoring of mitochondrial oxygenation and respiration in critical illness using a novel technique. Crit Care. 2015;19:343.

13. Hirakawa Y, Tanaka T, Nangaku M. Renal Hypoxia in CKD. Pathophysiology and detecting methods. Front Physiol. 2017;8:99.

14. Garcia-Alvarez M, Marik P, Bellomo R. Sepsis-associated hyperlactatemia. Crit Care. 2014;18:503.

15. Casserly B, Phillips GS, Schorr C, Dellinger RP, Townsend SR, Osborn TM, Reinhart K, Selvakumar N, Levy MM. Lactate measurements in sepsis-induced tissue hypoperfusion: results from the Surviving Sepsis Campaign database. Crit Care Med. 2015;43:567-73.

16. Hirota K. Involvement of hypoxia-inducible factors in the dysregulation of oxygen homeostasis in sepsis. Cardiovasc Hematol Disord Drug Targets. 2015;15:29-40.

17. Prabhakar NR, Semenza GL. Adaptive and maladaptive cardiorespiratory responses to continuous and intermittent hypoxia mediated by hypoxia-inducible factors 1 and 2 . Physiol Rev. 2012;92:967-1003.

18. Tamion F, Richard V, Lacoume Y, Thuillez C. Intestinal preconditioning prevents systemic inflammatory response in hemorrhagic shock. Role of HO-1. Am J Physiol Gastrointest Liver Physiol. 2002;283:408-14.

19. Nanduri J, Vaddi DR, Khan SA, Wang N, Makarenko V, Semenza GL, Prabhakar NR. HIF-1alpha activation by intermittent hypoxia requires NADPH oxidase stimulation by xanthine oxidase. PLoS ONE. 2015;10:e0119762.

20. Lee KF, Chong CCN, Cheung SYS, Wong J, Fung AKY, Lok HT, Lai PBS. Impact of intermittent pringle maneuver on long-term survival after hepatectomy for hepatocellular carcinoma: result from two combined randomized controlled trials. World J Surg. 2019;43:3101-9.

21. Martinez CA, Kerr B, Jin C, Cistulli PA, Cook KM. Obstructive sleep apnea activates HIF-1 in a hypoxia dose-dependent manner in HCT116 colorectal carcinoma cells. Int J Mol Sci. 2019;20:445.

22. Ryan S, Taylor CT, McNicholas WT. Selective activation of inflammatory pathways by intermittent hypoxia in obstructive sleep apnea syndrome. Circulation. 2005;112:2660-7.

23. Hunyor I, Cook KM. Models of intermittent hypoxia and obstructive sleep apnea: molecular pathways and their contribution to cancer. Am J Physiol Regul Integr Comp Physiol. 2018;315:R669-87.

24. Weir EK, Lopez-Barneo J, Buckler KJ, Archer SL. Acute oxygen-sensing mechanisms. N Engl J Med. 2005;353:2042-55.

25. Strielkov I, Pak O, Sommer N, Weissmann N. Recent advances in oxygen sensing and signal transduction in hypoxic pulmonary vasoconstriction. J Appl Physiol. 1985;2017(123):1647-56.

26. Bernardini A, Wolf A, Brockmeier U, Riffkin H, Metzen E, Acker-Palmer A, Fandrey J, Acker H. Carotid body Type I cells engage flavoprotein and Pin1 for oxygen sensing. Am J Physiol Cell Physiol. 2020;318:C719-31.

27. Semenza GL. Oxygen sensing, homeostasis, and disease. N Engl J Med. 2011;365:537-47.

28. Semenza GL. HIF-1 and human disease: one highly involved factor. Genes Dev. 2000;14:1983-91.

29. Semenza GL. Life with oxygen. Science. 2007;318:62-4.

30. Manalo DJ, Rowan A, Lavoie T, Natarajan L, Kelly BD, Ye SQ, Garcia JG, Semenza GL. Transcriptional regulation of vascular endothelial cell responses to hypoxia by HIF-1. Blood. 2005;105:659-69.

31. Wang G, Jiang B, Rue E, Semenza G. Hypoxia-inducible factor 1 is a basic-helix-loop-helix-PAS heterodimer regulated by cellular $\mathrm{O}_{2}$ tension. Proc Natl Acad Sci USA. 1995;92:5510-4.

32. Wang G, Semenza G. Purification and characterization of hypoxia-inducible factor 1. J Biol Chem. 1995;270:1230-7.

33. Bono H, Hirota K. Meta-analysis of hypoxic transcriptomes from public databases. Biomedicines. 2020;8:10.

34. Lee P, Chandel NS, Simon MC. Cellular adaptation to hypoxia through hypoxia inducible factors and beyond. Nat Rev Mol Cell Biol. 2020;21:268-83.

35. Hirota K, Semenza GL. Regulation of hypoxia-inducible factor 1 by prolyl and asparaginyl hydroxylases. Biochem Biophys Res Commun. 2005;338:610-6.

36. Ivan M, Kondo K, Yang H, Kim W, Valiando J, Ohh M, Salic A, Asara JM, Lane WS, Kaelin WG Jr. HIFalpha targeted for VHLmediated destruction by proline hydroxylation: implications for $\mathrm{O}_{2}$ sensing. Science. 2001;292:464-8.

37. Jaakkola P, Mole DR, Tian YM, Wilson MI, Gielbert J, Gaskell SJ, Kriegsheim A, Hebestreit HF, Mukherji M, Schofield CJ, Maxwell PH, Pugh CW, Ratcliffe PJ. Targeting of HIF-alpha to the von Hippel-Lindau ubiquitylation complex by $\mathrm{O}_{2}$-regulated prolyl hydroxylation. Science. 2001;292:468-72. 
38. Mahon PC, Hirota K, Semenza GL. FIH-1: a novel protein that interacts with HIF-1alpha and VHL to mediate repression of HIF-1 transcriptional activity. Genes Dev. 2001;15:2675-86.

39. Epstein A, Gleadle J, McNeill L, Hewitson K, O'Rourke J, Mole D, Mukherji M, Metzen E, Wilson M, Dhanda A, Tian Y, Masson N, Hamilton D, Jaakkola P, Barstead R, Hodgkin J, Maxwell P, Pugh C, Schofield C, Ratcliffe PC. elegans EGL-9 and mammalian homologs define a family of dioxygenases that regulate HIF by prolyl hydroxylation. Cell. 2001;107:43-54.

40. Lando D, Peet DJ, Whelan DA, Gorman JJ, Whitelaw ML. Asparagine hydroxylation of the HIF transactivation domain a hypoxic switch. Science. 2002;295:858-61.

41. Hirsila M, Koivunen P, Gunzler V, Kivirikko KI, Myllyharju J. Characterization of the human prolyl 4-hydroxylases that modify the hypoxia-inducible factor. J Biol Chem. 2003;278:30772-80.

42. Koivunen P, Hirsila M, Gunzler V, Kivirikko KI, Myllyharju J. Catalytic properties of the asparaginyl hydroxylase (FIH) in the oxygen sensing pathway are distinct from those of its prolyl 4-hydroxylases. J Biol Chem. 2004;279:9899-904.

43. Huang H, Benzonana LL, Zhao H, Watts HR, Perry NJ, Bevan C, Brown R, Ma D. Prostate cancer cell malignancy via modulation of HIF-1alpha pathway with isoflurane and propofol alone and in combination. Br J Cancer. 2014;111:1338-49.

44. Zhao H, Iwasaki M, Yang J, Savage S, Ma D. Hypoxia-inducible factor-1: a possible link between inhalational anesthetics and tumor progression? Acta Anaesthesiol Taiwan. 2014;52:70-6.

45. Benzonana LL, Perry NJ, Watts HR, Yang B, Perry IA, Coombes $\mathrm{C}$, Takata M, Ma D. Isoflurane, a commonly used volatile anesthetic, enhances renal cancer growth and malignant potential via the hypoxia-inducible factor cellular signaling pathway in vitro. Anesthesiology. 2013;119:593-605.

46. Luo X, Zhao H, Hennah L, Ning J, Liu J, Tu H, Ma D. Impact of isoflurane on malignant capability of ovarian cancer in vitro. $\mathrm{Br}$ J Anaesth. 2015;114:831-9.

47. Itoh T, Namba T, Fukuda K, Semenza GL, Hirota K. Reversible inhibition of hypoxia-inducible factor 1 activation by exposure of hypoxic cells to the volatile anesthetic halothane. FEBS Lett. 2001;509:225-9.

48. Takabuchi S, Hirota K, Nishi K, Oda S, Oda T, Shingu K, Takabayashi A, Adachi T, Semenza GL, Fukuda K. The intravenous anesthetic propofol inhibits hypoxia-inducible factor 1 activity in an oxygen tension-dependent manner. FEBS Lett. 2004;577:434-8.

49. Tanaka T, Takabuchi S, Nishi K, Oda S, Wakamatsu T, Daijo H, Fukuda K, Hirota K. The intravenous anesthetic propofol inhibits lipopolysaccharide-induced hypoxia-inducible factor 1 activation and suppresses the glucose metabolism in macrophages. $\mathbf{J}$ Anesth. 2010;24:54-60.

50. Ning HJ, Yuan HB, Xu HT, He XY. Propofol reduces hypoxiainduced autophagic cell death through downregulating HIF 1alpha in alveolar epithelial type II cells of rats. Mol Med Rep. 2017;16:1509-15.

51. Bellanti F, Mirabella L, Mitarotonda D, Blonda M, Tamborra R, Cinnella G, Fersini A, Ambrosi A, Dambrosio M, Vendemiale G, Serviddio G. Propofol but not sevoflurane prevents mitochondrial dysfunction and oxidative stress by limiting HIF-1alpha activation in hepatic ischemia/reperfusion injury. Free Radic Biol Med. 2016;96:323-33.

52. Ludbrook GL, Visco E, Lam AM. Propofol: relation between brain concentrations, electroencephalogram, middle cerebral artery blood flow velocity, and cerebral oxygen extraction during induction of anesthesia. Anesthesiology. 2002;97:1363-70.

53. Sumi C, Okamoto A, Tanaka H, Nishi K, Kusunoki M, Shoji T, Uba T, Matsuo Y, Adachi T, Hayashi JI, Takenaga K, Hirota K. Propofol induces a metabolic switch to glycolysis and cell death in a mitochondrial electron transport chain-dependent manner. PLoS ONE. 2018;13:e0192796.

54. Kishikawa JI, Inoue Y, Fujikawa M, Nishimura K, Nakanishi A, Tanabe T, Imamura H, Yokoyama K. General anesthetics cause mitochondrial dysfunction and reduction of intracellular ATP levels. PLoS ONE. 2018;13:e0190213.

55. Wakamatsu T, Tanaka T, Oda S, Nishi K, Harada H, Daijo H, Takabuchi S, Kai S, Fukuda K, Hirota K. The intravenous anesthetics barbiturates inhibit hypoxia-inducible factor 1 activation. Eur J Pharmacol. 2009;617:17-22.

56. Becker KE Jr. Plasma levels of thiopental necessary for anesthesia. Anesthesiology. 1978;49:192-6.

57. Matsuyama T, Tanaka T, Tatsumi K, Daijo H, Kai S, Harada H, Fukuda K. Midazolam inhibits the hypoxia-induced up-regulation of erythropoietin in the central nervous system. Eur J Pharmacol. 2015;761:189-98.

58. Yan J, Huang Y, Lu Y, Chen J, Jiang H. Repeated administration of ketamine can induce hippocampal neurodegeneration and long-term cognitive impairment via the ROS/HIF-1alpha pathway in developing rats. Cell Physiol Biochem. 2014;33:1715-32.

59. Gao Y, Yin H, Zhang Y, Dong Y, Yang F, Wu X, Liu H. Dexmedetomidine protects hippocampal neurons against hypoxia/ reoxygenation-induced apoptosis through activation HIF-1alpha/ p53 signaling. Life Sci. 2019;232:116611.

60. Zhang W, Zhang JQ, Meng FM, Xue FS. Dexmedetomidine protects against lung ischemia-reperfusion injury by the PI3K/Akt/ HIF-1alpha signaling pathway. J Anesth. 2016;30:826-33.

61. Zhang F, Ding T, Yu L, Zhong Y, Dai H, Yan M. Dexmedetomidine protects against oxygen-glucose deprivation-induced injury through the $\mathrm{I} 2$ imidazoline receptor-PI3K/AKT pathway in rat C6 glioma cells. J Pharm Pharmacol. 2012;64:120-7.

62. Wang C, Datoo T, Zhao H, Wu L, Date A, Jiang C, Sanders RD, Wang G, Bevan C, Ma D. Midazolam and dexmedetomidine affect neuroglioma and lung carcinoma cell biology in vitro and in vivo. Anesthesiology. 2018;129:1000-14.

63. Weerink MAS, Struys M, Hannivoort LN, Barends CRM, Absalom AR, Colin P. Clinical pharmacokinetics and pharmacodynamics of dexmedetomidine. Clin Pharmacokinet. 2017;56:893-913.

64. Schwagmeier R, Alincic S, Striebel HW. Midazolam pharmacokinetics following intravenous and buccal administration. $\mathrm{Br}$ J Clin Pharmacol. 1998;46:203-6.

65. Daijo H, Kai S, Tanaka T, Wakamatsu T, Kishimoto S, Suzuki K, Harada H, Takabuchi S, Adachi T, Fukuda K, Hirota K. Fentanyl activates hypoxia-inducible factor 1 in neuronal SH-SY5Y cells and mice under non-hypoxic conditions in a mu-opioid receptordependent manner. Eur J Pharmacol. 2011;667:144-52.

66. Koodie L, Ramakrishnan S, Roy S. Morphine suppresses tumor angiogenesis through a HIF-1alpha/p38MAPK pathway. Am J Pathol. 2010;177:984-97.

67. Salman S, Holloway AC, Nurse CA. Chronic opioids regulate KATP channel subunit Kir6.2 and carbonic anhydrase I and II expression in rat adrenal chromaffin cells via HIF-2alpha and protein kinase A. Am J Physiol Cell Physiol. 2014;307:266-77.

68. Nishi K, Hirota K, Takabuchi S, Oda S, Fukuda K, Adachi T, Shingu K. The effects of local anesthetics on cellular hypoxiainduced gene responses mediated by hypoxia-inducible factor 1 . J Anesth. 2005;19:54-9.

69. Chan SM, Lin BF, Wong CS, Chuang WT, Chou YT, Wu ZF. Levobuipivacaine-induced dissemination of A549 lung cancer cells. Sci Rep. 2017;7:8646.

70. Takabuchi S, Hirota K, Nishi K, Oda S, Oda T, Shingu T, Takabayashi A, Adachi T, Semenza GL, Fukuda K. The inhibitory effect of sodium nitroprusside on HIF-1 activation is not 
dependent on nitric oxide- soluble guanylyl cyclase pathway. Biochem Biophys Res Commun. 2004;324:417-23.

71. Suzuki K, Nishi K, Takabuchi S, Kai S, Matsuyama T, Kurosawa S, Adachi T, Maruyama T, Fukuda K, Hirota K. Differential roles of prostaglandin E-type receptors in activation of hypoxiainducible factor 1 by prostaglandin E1 in vascular-derived cells under non-hypoxic conditions. PeerJ. 2013;1:e220.

72. Oda S, Oda T, Takabuchi S, Nishi K, Wakamatsu T, Tanaka T, Adachi T, Fukuda K, Nohara R, Hirota K. The calcium channel blocker cilnidipine selectively suppresses hypoxia-inducible factor 1 activity in vascular cells. Eur J Pharmacol. 2009;606:130-6.

73. Tanaka T, Kai S, Koyama T, Daijo H, Adachi T, Fukuda K, Hirota K. General anesthetics inhibit erythropoietin induction under hypoxic conditions in the mouse brain. PLoS ONE. 2011;6:29378.

74. Kai S, Tanaka T, Matsuyama T, Suzuki K, Hirota K. The volatile anesthetic isoflurane differentially suppresses the induction of erythropoietin synthesis elicited by acute anemia and systemic hypoxemia in mice in an hypoxia-inducible factor2-dependent manner. Eur J Pharmacol. 2014;732C:43-9.

75. Yap DYH, McMahon LP, Hao CM, Hu N, Okada H, Suzuki Y, Kim SG, Lim SK, Vareesangthip K, Hung CC, Nangaku M, Committee AH-PR. Recommendations by the Asian Pacific society of nephrology (APSN) on the appropriate use of HIFPH inhibitors. Nephrology (Carlton). 2020;26:105-18.

76. Gupta N, Wish JB. Hypoxia-inducible factor prolyl hydroxylase inhibitors: a potential new treatment for anemia in patients with CKD. Am J Kidney Dis. 2017;69:815-26.

77. Chen N, Hao C, Liu BC, Lin H, Wang C, Xing C, Liang X, Jiang G, Liu Z, Li X, Zuo L, Luo L, Wang J, Zhao MH, Liu Z, Cai GY, Hao L, Leong R, Wang C, Liu C, Neff T, Szczech L, $\mathrm{Yu}$ KP. Roxadustat treatment for anemia in patients undergoing long-term dialysis. N Engl J Med. 2019;381:1011-22.

78. Chen N, Hao C, Peng X, Lin H, Yin A, Hao L, Tao Y, Liang X, Liu Z, Xing C, Chen J, Luo L, Zuo L, Liao Y, Liu BC, Leong R, Wang C, Liu C, Neff T, Szczech L, Yu KP. Roxadustat for anemia in patients with kidney disease not receiving dialysis. N Engl J Med. 2019;381:1001-10.

79. Yan Z, Xu G. A novel choice to correct inflammation-induced anemia in CKD: oral hypoxia-inducible factor prolyl hydroxylase inhibitor roxadustat. Front Med (Lausanne). 2020;7:393.

80. Mole DR, Maxwell PH, Pugh CW, Ratcliffe PJ. Regulation of HIF by the von Hippel-Lindau tumour suppressor: implications for cellular oxygen sensing. IUBMB Life. 2001;52:43-7.

81. Singer M, Deutschman CS, Seymour CW, Shankar-Hari M, Annane D, Bauer M, Bellomo R, Bernard GR, Chiche JD, Coopersmith CM, Hotchkiss RS, Levy MM, Marshall JC, Martin GS, Opal SM, Rubenfeld GD, van der Poll T, Vincent JL, Angus DC. The Third International Consensus Definitions for Sepsis and Septic shock (Sepsis-3). JAMA. 2016;315:801-10.

82. Shankar-Hari M, Phillips GS, Levy ML, Seymour CW, Liu VX, Deutschman CS, Angus DC, Rubenfeld GD, Singer M, Sepsis Definitions Task F. Developing a new definition and assessing new clinical criteria for septic shock: for the Third International Consensus Definitions for Sepsis and Septic Shock (Sepsis-3). JAMA. 2016;315:775-87.

83. Suetrong B, Walley KR. Lactic acidosis in sepsis: it's not all anaerobic: implications for diagnosis and management. Chest. 2016;149:252-61.

84. Kam PC, Cardone D. Propofol infusion syndrome. Anaesthesia. 2007;62:690-701.

85. Krajcova A, Waldauf P, Andel M, Duska F. Propofol infusion syndrome: a structured review of experimental studies and 153 published case reports. Crit Care. 2015;19:398.

86. Vanlander AV, Okun JG, de Jaeger A, Smet J, De Latter E, De Paepe B, Dacremont G, Wuyts B, Vanheel B, De Paepe P,
Jorens PG, Van Regenmortel N, Van Coster R. Possible pathogenic mechanism of propofol infusion syndrome involves coenzyme q. Anesthesiology. 2015;122:343-52.

87. Fudickar A, Bein B. Propofol infusion syndrome: update of clinical manifestation and pathophysiology. Minerva Anestesiol. 2009;75:339-44.

88. Hiller JG, Perry NJ, Poulogiannis G, Riedel B, Sloan EK. Perioperative events influence cancer recurrence risk after surgery. Nat Rev Clin Oncol. 2018;15:205-18.

89. Tedore T. Regional anaesthesia and analgesia: relationship to cancer recurrence and survival. Br J Anaesth. 2015;115(Suppl 2):34-45.

90. Soltanizadeh S, Degett TH, Gogenur I. Outcomes of cancer surgery after inhalational and intravenous anesthesia: a systematic review. J Clin Anesth. 2017;42:19-25.

91. Boland JW, Pockley AG. Influence of opioids on immune function in patients with cancer pain: from bench to bedside. Br J Pharmacol. 2018;175:2726-36.

92. Snyder GL, Greenberg S. Effect of anaesthetic technique and other perioperative factors on cancer recurrence. $\mathrm{Br} \mathrm{J}$ Anaesth. 2010;105:106-15.

93. Irwin MG, Chung CKE, Ip KY, Wiles MD. Influence of propofolbased total intravenous anaesthesia on peri-operative outcome measures: a narrative review. Anaesthesia. 2020;75(Suppl 1):e90-100.

94. Tohme S, Simmons RL, Tsung A. Surgery for cancer: a trigger for metastases. Cancer Res. 2017;77:1548-52.

95. Semenza GL. Hypoxia-inducible factors: mediators of cancer progression and targets for cancer therapy. Trends Pharmacol Sci. 2012;33:207-14.

96. Zhang Y, Weinberg RA. Epithelial-to-mesenchymal transition in cancer: complexity and opportunities. Front Med. 2018:12:361-73.

97. Keith B, Simon MC. Hypoxia-inducible factors, stem cells, and cancer. Cell. 2007;129:465-72.

98. Kim JW, Dang CV. Cancer's molecular sweet tooth and the Warburg effect. Cancer Res. 2006;66:8927-30.

99. Li QF, Wang XR, Yang YW, Su DS. Up-regulation of hypoxia inducible factor 1alpha by isoflurane in Hep3B cells. Anesthesiology. 2006;105:1211-9.

100. Wang G, Semenza G. Characterization of hypoxia-inducible factor 1 and regulation of DNA binding activity by hypoxia. J Biol Chem. 1993;268:21513-8.

101. Brown JM, Wilson WR. Exploiting tumour hypoxia in cancer treatment. Nat Rev Cancer. 2004;4:437-47.

102. Keith B, Johnson RS, Simon MC. HIF1alpha and HIF2alpha: sibling rivalry in hypoxic tumour growth and progression. Nat Rev Cancer. 2011;12:9-22.

103. Koppenol WH, Bounds PL, Dang CV. Otto Warburg's contributions to current concepts of cancer metabolism. Nat Rev Cancer. 2011;11:325-37.

104. Sumi C, Matsuo Y, Kusunoki M, Shoji T, Uba T, Iwai T, Bono H, Hirota K. Cancerous phenotypes associated with hypoxiainducible factors are not influenced by the volatile anesthetic isoflurane in renal cell carcinoma. PLoS ONE. 2019;14:e0215072.

105. Liang H, Yang CX, Zhang B, Wang HB, Liu HZ, Lai XH, Liao MJ, Zhang T. Sevoflurane suppresses hypoxia-induced growth and metastasis of lung cancer cells via inhibiting hypoxia-inducible factor-1alpha. J Anesth. 2015;29:821-30.

106. Zhang W, Sheng B, Chen S, Zhao H, Wu L, Sun Y, Cui J, Zhu X, Ma D. Sevoflurane enhances proliferation, metastatic potential of cervical cancer cells via the histone deacetylase 6 modulation in vitro. Anesthesiology. 2020;132:1469-81.

107. Ciechanowicz S, Zhao H, Chen Q, Cui J, Mi E, Mi E, Lian Q, Ma D. Differential effects of sevoflurane on the metastatic potential 
and chemosensitivity of non-small-cell lung adenocarcinoma and renal cell carcinoma in vitro. Br J Anaesth. 2018;120:368-75.

108. Ishikawa M, Sakamoto A, Ma D. Recurrence of breast cancer after anaesthesia. Lancet. 2020;396:375-6.

109. Wall T, Sherwin A, Ma D, Buggy DJ. Influence of perioperative anaesthetic and analgesic interventions on oncological outcomes: a narrative review. Br J Anaesth. 2019;123:135-50.

110. Perry NJS, Buggy D, Ma D. Can anesthesia influence cancer outcomes after surgery? JAMA Surg. 2019;154:279-80.

111. Buggy DJ, Borgeat A, Cata J, Doherty DG, Doornebal CW, Forget P, Gottumukkala V, Gottschalk A, Gupta A, Gupta K, Hales TG, Hemmings HC, Hollmann MW, Kurz A, Ma D, Parat MO, Sessler DI, Shorten G, Singleton P. Consensus statement from the BJA Workshop on Cancer and Anaesthesia. Br J Anaesth. 2015;114:2-3.

112. Hanahan D, Weinberg RA. Hallmarks of cancer: the next generation. Cell. 2011;144:646-74.

113. Hanahan D, Weinberg RA. The hallmarks of cancer. Cell. 2000;100:57-70.

114. Jahani M, Dokaneheifard S, Mansouri K. Hypoxia: a key feature of COVID-19 launching activation of HIF-1 and cytokine storm. J Inflamm (Lond). 2020;17:33.

115. Nishi K, Oda T, Takabuchi S, Oda S, Fukuda K, Adachi T, Semenza GL, Shingu K, Hirota K. LPS induces hypoxia-inducible factor 1 activation in macrophage-differentiated cells in a reactive oxygen species-dependent manner. Antioxid Redox Signal. 2008;10:983-96.

116. Hirota K. Hypoxia and hypoxia-inducible factor in inflammation. In: Roy S, editor. Chronic inflammation: molecular pathophysiology, nutritional and therapeutic interventions. New Jersey: Taylor and Francis; 2012. p. 51-65.

117. Siebert JN, Posfay-Barbe KM, Habre W, Siegrist CA. Influence of anesthesia on immune responses and its effect on vaccination in children: review of evidence. Paediatr Anaesth. 2007;17:410-20.

118. Porteous GH, Hanson NA, Sueda LA, Hoaglan CD, Dahl AB, Ohlson BB, Schmidt BE, Wang CC, Fagley RE. Resurgence of vaccine-preventable diseases in the united states: anesthetic and critical care implications. Anesth Analg. 2016;122:1450-73.

119. Lim JA, Oh CS, Yoon TG, Lee JY, Lee SH, Yoo YB, Yang $\mathrm{JH}, \mathrm{Kim} \mathrm{SH}$. The effect of propofol and sevoflurane on cancer cell, natural killer cell, and cytotoxic T lymphocyte function in patients undergoing breast cancer surgery: an in vitro analysis. BMC Cancer. 2018;18:159.

120. Stollings LM, Jia LJ, Tang P, Dou H, Lu B, Xu Y. Immune modulation by volatile anesthetics. Anesthesiology. 2016;125:399-411.

121. Steinberg BE, Sundman E, Terrando N, Eriksson LI, Olofsson PS. Neural control of inflammation: implications for perioperative and critical care. Anesthesiology. 2016;124:1174-89.

122. Sitkovsky MV. T regulatory cells: hypoxia-adenosinergic suppression and re-direction of the immune response. Trends Immunol. 2009;30:102-8.

123. Barbi J, Pardoll D, Pan F. Metabolic control of the Treg/Th17 axis. Immunol Rev. 2013;252:52-77.

124. Dang EV, Barbi J, Yang HY, Jinasena D, Yu H, Zheng Y, Bordman Z, Fu J, Kim Y, Yen HR, Luo W, Zeller K, Shimoda L, Topalian SL, Semenza GL, Dang CV, Pardoll DM, Pan F. Control of $\mathrm{T}(\mathrm{H}) 17 / \mathrm{T}(\mathrm{reg})$ balance by hypoxia-inducible factor 1 . Cell. 2011;146:772-84.

125. Nutsch K, Hsieh C. When T cells run out of breath: the HIF1alpha story. Cell. 2011;146:673-4.

126. Clambey ET, McNamee EN, Westrich JA, Glover LE, Campbell EL, Jedlicka P, de Zoeten EF, Cambier JC, Stenmark KR, Colgan SP, Eltzschig HK. Hypoxia-inducible factor-1 alpha-dependent induction of FoxP3 drives regulatory T-cell abundance and function during inflammatory hypoxia of the mucosa. Proc Natl Acad Sci USA. 2012;109:E2784-93.

127. Dehne N, Brune B. HIF-1 in the inflammatory microenvironment. Exp Cell Res. 2009;315:1791-7.

128. Nizet V, Johnson RS. Interdependence of hypoxic and innate immune responses. Nat Rev Immunol. 2009;9:609-17.

129. Taylor CT, Colgan SP. Regulation of immunity and inflammation by hypoxia in immunological niches. Nat Rev Immunol. 2017;17:774-85.

130. Rius J, Guma M, Schachtrup C, Akassoglou K, Zinkernagel AS, Nizet V, Johnson RS, Haddad GG, Karin M. NF-kappaB links innate immunity to the hypoxic response through transcriptional regulation of HIF-1alpha. Nature. 2008;453:807-11.

131. Oda T, Hirota K, Nishi K, Takabuchi S, Oda S, Yamada H, Arai T, Fukuda K, Kita T, Adachi T, Semenza GL, Nohara R. Activation of hypoxia-inducible factor 1 during macrophage differentiation. Am J Physiol Cell Physiol. 2006;291:C104-13.

132. Cho SH, Raybuck AL, Stengel K, Wei M, Beck TC, Volanakis E, Thomas JW, Hiebert S, Haase VH, Boothby MR. Germinal centre hypoxia and regulation of antibody qualities by a hypoxia response system. Nature. 2016;537:234-8.

133. Burrows N, Maxwell PH. Hypoxia and B cells. Exp Cell Res. 2017;356:197-203.

134. Couzin-Frankel J. The mystery of the pandemic's "happy hypoxia." Science. 2020;368:455-6.

135. Wadman M, Couzin-Frankel J, Kaiser J, Matacic C. A rampage through the body. Science. 2020;368:356-60.

136. Wichmann D, Sperhake JP, Lutgehetmann M, Steurer S, Edler C, Heinemann A, Heinrich F, Mushumba H, Kniep I, Schroder AS, Burdelski C, de Heer G, Nierhaus A, Frings D, Pfefferle S, Becker H, Bredereke-Wiedling H, de Weerth A, Paschen HR, Sheikhzadeh-Eggers S, Stang A, Schmiedel S, Bokemeyer C, Addo MM, Aepfelbacher M, Puschel K, Kluge S. Autopsy Findings and venous thromboembolism in patients with COVID-19: a prospective cohort study. Ann Intern Med. 2020;173:268-77.

137. Fink T, Kazlauskas A, Poellinger L, Ebbesen P, Zachar V. Identification of a tightly regulated hypoxia-response element in the promoter of human plasminogen activator inhibitor-1. Blood. 2002;99:2077-83.

138. Pottier P, Planchon B, Truchaud F, Leftheriotis G, Herbert JM, Bressolette L, Trewick D, Passuti N. Development of an experimental model of pre-thrombosis in rats based on Wessler's principle using a calibrated venous stasis. Blood Coagul Fibrinolysis. 2003;14:3-9.

139. Prchal JT. Hypoxia and thrombosis. Blood. 2018;132:348-9.

140. Cui XY, Skretting G, Tinholt M, Stavik B, Dahm AEA, Sahlberg KK, Kanse S, Iversen N, Sandset PM. A novel hypoxia response element regulates oxygen-related repression of tissue factor pathway inhibitor in the breast cancer cell line MCF-7. Thromb Res. 2017;157:111-6.

141. Cui XY, Tinholt M, Stavik B, Dahm AE, Kanse S, Jin Y, Seidl S, Sahlberg KK, Iversen N, Skretting G, Sandset PM. Effect of hypoxia on tissue factor pathway inhibitor expression in breast cancer. J Thromb Haemost. 2016;14:387-96.

142. Stavik B, Espada S, Cui XY, Iversen N, Holm S, Mowinkel MC, Halvorsen B, Skretting G, Sandset PM. EPAS1/HIF-2 alphamediated downregulation of tissue factor pathway inhibitor leads to a pro-thrombotic potential in endothelial cells. Biochim Biophys Acta. 2016;1862:670-8.

143. Chauhan A, Kaur R, Chakrbarti P, Pal A. "Silent hypoxemia" leads to vicious cycle of infection, coagulopathy and cytokine storm in COVID-19: can prophylactic oxygen therapy prevent it? Indian J Clin Biochem. 2021. https://doi.org/10.1007/ s12291-021-00967-0.

144. Serebrovska ZO, Chong EY, Serebrovska TV, Tumanovska LV, Xi L. Hypoxia, HIF-1 $\alpha$, and COVID-19: from pathogenic 
factors to potential therapeutic targets. Acta Pharmacol Sin. 2020;41:1539-46.

145. Koch A, Kahler W, Klapa S, Grams B, van Ooij PAM. The conundrum of using hyperoxia in COVID-19 treatment strategies: may intermittent therapeutic hyperoxia play a helpful role in the expression of the surface receptors ACE2 and Furin in lung tissue via triggering of HIF-1alpha? Intensive Care Med Exp. 2020;8:53.

Publisher's Note Springer Nature remains neutral with regard to jurisdictional claims in published maps and institutional affiliations. 